\title{
Microstructure and Mechanical Properties of Borided Inconel 625 Superalloy
}

Ali Gunen ${ }^{1}$, Erdogan Kanca ${ }^{2}$

\author{
${ }^{1}$ Metallurgical and Materials Engineering, Technology Faculty, Iskenderun Technical University,31200 Hatay, Turkey \\ e-mail: ali.gunen@iste.edu.tr, aligunen2013@gmail.com \\ ${ }^{2}$ Mechanical Engineering, Mechanical Engineering Faculty, Iskenderun Technical University,31200 Hatay, Turkey \\ e-mail: erdogan.kanca@iste.edu.tr
}

\begin{abstract}
The Ni- based superalloy Inconel 625 is extensively used owing to its high strength, excellent fabricability, good weldability and outstanding resistance to high temperature corrosion against aggressive environments. However, despite its unique properties and extensive use, its wear resistance is in some cases unsatisfactory. In this study, Inconel 625 was subjected to boriding treatments at different temperature and different durations. Microstructural characterization was made by conventional methods (scanning electron microscopy, optic microscopy, X-ray diffraction analysis) and mechanical characterization was made by microhardness and micro-abrasion wear test. Micro-abrasion wear tests were conducted against a AISI 52100 steel under 5, 7.5 and $10 \mathrm{~N}$ load in a $25 \mathrm{wt} \% \mathrm{SiC}$ slurry at room temperature. Microstructural results revealed that multi-phase boride layer (nickel boride, chrome boride and iron boride) and silicide layer were formed. The hardness and thickness of the boride layers were found to be $1175-2432 \mathrm{HV}_{0.1}$ and, $6.61-92.03$ $\mu \mathrm{m}$, respectively. Depending on the boriding temperature and time. In spite of silicide layer formation the wear resistance of borided Inconel 625 alloy increased up to 8 times thanks to the increase in the surface hardness which was caused by boriding process. The boriding treatment caused a transition in the wear mechanism. While grooving was observed in the untreated Inconel 625 samples, mixed (grooving and rolling) and rolling type wear was predominant in the borided samples.
\end{abstract}

Keywords: Ni-based superalloy, Coating, Microstructure, Mechanical properties, Wear.

\section{INTRODUCTION}

Superalloys or high-performance alloys are materials that are capable of retaining their mechanical properties and surface stability even at high temperatures [1]. The first superalloys were mere modifications of austenitic stainless steels and many of the superalloy in use today were developed between the 1950 and 1970 s. Toward the 1980s, super alloys gained improved mechanical properties with the addition of specific alloying elements [1, 2].

Superalloys are characterized by their inherent resistance to oxidation and corrosion, resistance to thermal creep deformation and excellent high temperature mechanical strength. Because of these properties superalloys are used in many advanced engineering applications such as turbo aircraft and superchargers turbine engines, land-based and aircraft gas turbines, rocket engines, chemical, and petroleum plants and other challenging environments [1-3].

Superalloys are based on group VIII elements and classified into three groups according to the main alloying element in their composition as that nickel, iron-nickel and cobalt-based. On the other hand the commercial classifications are Inconel, Hastelloy, Hayness alloys, Waspaloy, Rene alloys, Incoloy, MPT98T, TMS alloys and CMSX single crystal alloys [1].

Ni-based superalloys have gained attention for a wide range of industrial applications due to their high temperature strength, microstructural stability, fatigue strength, tensile properties and creep performance compared to their Co-based and Fe-Ni-based counterparts [1,3]. Ni-based Inconel 625 has especially found widespread use in aerospace, marine, chemical and petrochemical industries at service temperatures ranging from cryogenic to $982{ }^{\circ} \mathrm{C}$ due to its superior mechanical and corrosion resistance properties. However, due to the low surface hardness If it is to be used in abrasive or adhesive wear conditions it does require proper 
surface protection against wear [4].

For this reason, many processes were developed in order to improve the tribological properties of Nibased Inconel 625 by applying protective coatings with methods such as plasma spray coating, selective laser melting, CVD aluminide coating, nitridig, etc. However, there are some disadvantages such as poor adhesion bond between the coating layer and the substrate in thermal spray, longer processing periods in CVD coating process, formation of pores and cracks in laser melting process and relatively thin layers in nitriding even after very ong durations ( 6 to $40 \mathrm{~h}$ ) indicates the necessity for new, alternative coating methods [2,3]. On the other hand, it has been found that only a few studies related to the boriding of Ni-based superalloys [5-10]. This has triggered the current study which focuses on the boriding of the Ni-based Inconel 625 superalloy.

Boriding is a well-known thermo chemical surface modification process in which boron atoms (thanks to their relatively small atomic radius) diffuse into the matrix and form chemically bonded hard phases ( based on the chemical compositions such as $\mathrm{Fe}_{\mathrm{x}} \mathrm{B}_{\mathrm{y}}, \mathrm{Cr}_{\mathrm{x}} \mathrm{B}_{\mathrm{y}}, \mathrm{Ni}_{\mathrm{x}} \mathrm{B}_{\mathrm{y}}$ ) with the substrate metal. In order to obtain a suited boride layer, the boriding treatment is generally applied at temperatures $700-1050{ }^{\circ} \mathrm{C}$ and for the durations differencing from 30 minutes to 12 hs [11]. Many different boron compounds can be used as boriding agents for the boriding treatment based on the selected boriding method. Boriding can be implemented by many different boriding techniques, such as pack boriding, molten salt boriding, gas boriding, paste boriding, and plasma boriding. Among these techniques pack boriding is the most commonly used technique owing to its simplicity, technology and cost-effectiveness methods [11,12].

The characteristic features of the boride layers formed on the surface are high hardness, low coefficient of friction and high wear resistance (even at high temperature). Many studies in the literature have stated that borided materials can show much better wear resistance when compared with the nitrided, carbonitrided, carburized or hard chrome plated materials [8]. Moreover boride layers exhibit abrasion and wear resistance comparable to sintered carbides [11].

Boride coatings have a prominent place in industrial applications. Although primary boriding treatments were applied overly to ferrous alloys (Low C steels, C steels, tool steels, stainless steels, etc.) [11$13,18,19]$ they are recently being applied to many groups of alloys such including non- ferrous metals and cermets. However the boriding of superalloys is relatively new and studies studies on this subject are limited [5-10].

Previous studies have shown that the hardness of the Ni-based superalloys can be increased up to 1500 HV $[7,8,10]$. Moreover, the friction coefficient decreases and wear resistant improves by the process [5-10]. However, there are only very few studies exist on the micro-abrasion wear behavior of Ni-based superalloys. The purpose of this study, therefore, is to investigate the micro-abrasion wear behavior of Ni-based Inconel 625 superalloys, borided at different temperature and durations, under different loads in a $25 \mathrm{wt} . \% \mathrm{SiC}$ slurry..Then effect of boriding parameters on wear resistance and wear mechanisms of Ni-based superalloy are evaluated.

\section{MATERIALS AND METHODS}

Ni-based Inconel 625 was chosen as the substrate alloy for this study. Chemical analysis of the alloy was carried out utilizing a Thermo Jarrell Ash/Baird DV-6S 3063A spectral analyzer and given in Table 1. Prior to the boriding treatment, $40 \times 40 \times 5 \mathrm{~mm}$ rectangular samples were cut from $5-\mathrm{mm}$ thick alloy sheet.. All samples were ground using 1200 grit $\mathrm{SiC}$ paper and then washed in distilled water and ultrasonically cleaned in acetone for 10 minutes. The samples were then packed with commercially Ekabor II powders in a stainless steel container. Boriding was performed at 800,900 and $1200^{\circ} \mathrm{C}$ for 2, 4, and $6 \mathrm{~h}$. Commercial Ekrit powders (finely ground $\mathrm{SiC}$ ) were added as a thin layer to minimize oxidation. After boriding, the steel container was removed from the furnace and allowed to cool in open air.

Table 1: Chemical composition (wt.\%) of the Inconel 625 Ni-based superalloy used in experimental studies

\begin{tabular}{c|c|c|c|c|c|c|c|c|c}
\hline $\mathbf{N i}$ & $\mathbf{C r}$ & $\mathbf{M o}$ & $\mathbf{F e}$ & $\mathbf{N b}$ & $\mathbf{C o}$ & $\mathbf{M n}$ & $\mathbf{S i}$ & $\mathbf{A l}$ & $\mathbf{T i}$ \\
\hline 58 & 22 & 9.1 & 5 & 3.10 & 1 & 0.5 & 0.50 & 0.40 & 0.40 \\
\hline
\end{tabular}

The borided samples were cut to dimensions of $10 \times 10 \times 5 \mathrm{~mm}$, cold mounted and then ground with up to 1500 grit $\mathrm{SiC}$ papers and polished with $0.25 \mu \mathrm{m}$ alumina paste followed by $1 \mu \mathrm{m}$ diamond paste to obtain a good surface finish. The polished samples were then etched with a solution of $5 \mathrm{ml} \mathrm{HNO} \mathrm{Hl}_{3} \mathrm{ml}, 10 \mathrm{CH}_{3} \mathrm{COOH}$ $\mathrm{ml}$ and $15 \mathrm{HCI} \mathrm{ml}$ to reveal fine microstructural details. 
Metallographic studies were carried out using a Nikon MA-200 inverted metallurgical microscope equipped with Clemex Vision software. Scanning Electron Microscopy (SEM) studies were conducted using a JEOL JSM-5600 SEM equipped with Energy Dispersive Spectroscopy (EDS) capability, at $25 \mathrm{kV}$ accelerating voltage. Microhardness values of boride layers were obtained by utilizing a Highwood HWMMT-X3 hardness tester using $100 \mathrm{~g}$ load and $15 \mathrm{~s}$ dwell time. Hardness measurements on silicide layers were made by using $25 \mathrm{~g}$ load after cracking was observed at 100 and $50 \mathrm{~g}$ load. The thicknesses of produced layers were determined by a Clemex digital thickness measurement instrument attached to a Nikon MA-200 optical microscope. X-ray diffraction analyses (XRD) were carried out using a computer-controlled Bruker AXS D8 Advance with $\mathrm{Cu} \mathrm{K \alpha}$ radiation $(\lambda \mathrm{Cu}=0.1540 \mathrm{~nm})$ and $2 \theta$ angles ranging from $10^{\circ}$ to $90^{\circ}$.

The fixed-ball micro abrasion wear test was performed for untreated and borided samples. The ball used in this test had a diameter of $25.4 \mathrm{~mm}$ and was made of AISI 52100 steel. Prior to each test, surface samples and ball were ultrasonically cleaned in acetone for 5 minutes and then air dried. Silicon carbide ( $\mathrm{SiC}$ ) was used as the abrasive with an average particle size smaller than 800 mesh. The abrasive slurry was created with 25 wt.\% SiC in distilled water. The rotational speed of the ball was set to $90 \mathrm{rpm}$ the course of these tests, abrasive slurry was dropped as $0.2 \mathrm{ml}$ in every 20 seconds. The total test time for each sample was determined as 3 minute. Each test was repeated three times. Radius wear crater determined via SEM and volume loss of the worn samples calculated by using the equation:.

$$
V=\frac{\pi \cdot B^{4}}{64 . R}
$$

Where, where, $B$ is the outer diameter of the crater in $\mathrm{mm}$ and $R$ is the radius of the ball used in the wear test $(12.7 \mathrm{~mm})$.

\section{RESULTS AND DISCUSSIONS}

\subsection{Microstructures}

Figure 1 shows the microstructure of the untreated commercial Inconel 625 alloy.

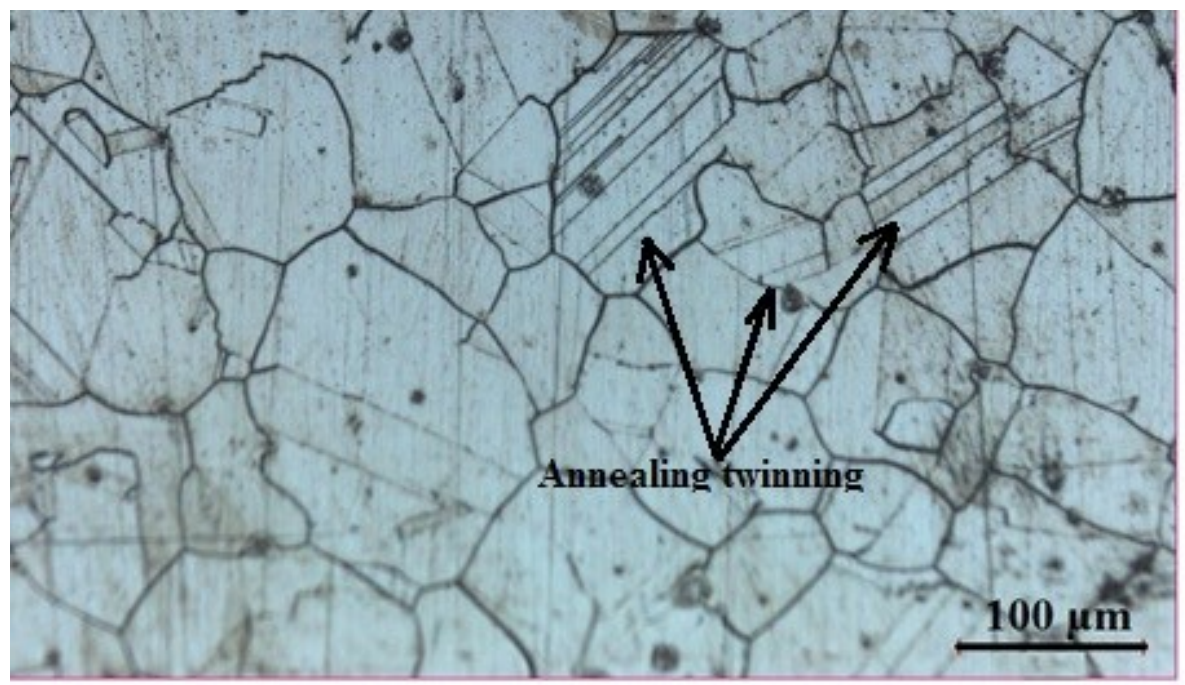

Figure 1: Microstructure of commercially Inconel 625 Ni-based superalloy.

Considering Annealing twinning was clearly seen in some grains. This type of defect is frequently encountered in metal and alloys with face centered cubic structures. When analyzed under a microscope, annealing twins are characterized by straight lines extending across a grain boundaries (Figure 1). 
OM micrographs of the box borided layer formed on Inconel 625 superalloy at the temperatures 800 , 900 and $1000{ }^{\circ} \mathrm{C}$ for $4 \mathrm{~h}$ with Ekabor II powder were shown in Figure 2a-2c, respectively.
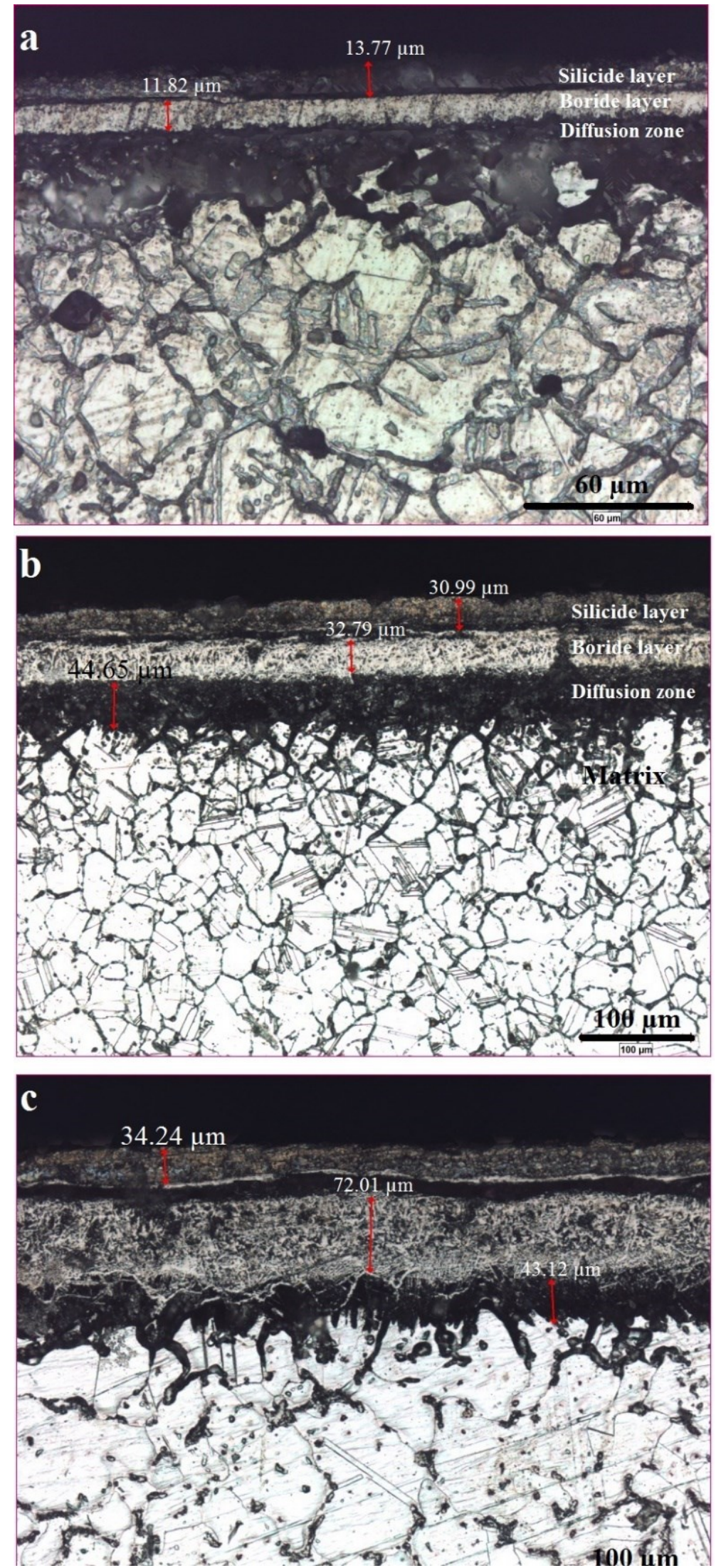

Figure 2: Optical micrographs of the samples borided at $800^{\circ} \mathrm{C}$ (a) $900{ }^{\circ} \mathrm{C}$ (b) $1000{ }^{\circ} \mathrm{C}$ and (c) for $4 \mathrm{~h}$. 
As seen from Figure 2 the borided samples consisted of three distinct layers. As stated in the previous study these layer has been ranked from to the surface inwards as silicide layer, multi-phase boride layer and diffusion zone, respectively [5-7, 8, 9]. The boride/silicide volume ratio is higher than the ratios observed in previous studies [6,7]. This situation is thought to be the result of $\mathrm{Ar}$ atmosphere and used $\mathrm{Al}_{2} \mathrm{O}_{3} \mathrm{Ekrit}$ powder. Because silicide layer rates decreased with increasing process duration times. This can be explained in this way the oxygen, which entered to crucible during charging, is reduced with time. Thus achieving a lower silicide and a higher boride layers. The thickness of boride layer and silicide were close to each other at $2 \mathrm{~h}$ whereas at high duration the ratio of boride layer increased to 2-3 times (Table 2).

\subsection{Microhardness and thickness of produced layers}

The measured hardness and thickness values for the silicide and boride layers and the diffusion zones depending on boriding process conditions, are listed in Table 2.

Table 2: Hardness and thickness of produced layer

\begin{tabular}{|c|c|c|c|c|c|c|}
\hline \multirow{2}{*}{ Named } & \multirow{2}{*}{$\begin{array}{c}\text { Boriding } \\
\text { Conditions }\end{array}$} & \multicolumn{2}{|c|}{ Silicide layer } & \multicolumn{2}{|c|}{ Boride layer } & \multirow{2}{*}{$\begin{array}{c}\text { Layer } \\
\text { thickness } \\
\text { Diffusion } \\
\text { zone }(\mu \mathrm{m})\end{array}$} \\
\hline & & $\begin{array}{c}\text { Thickness } \\
\text { ( } \mu \mathrm{m})\end{array}$ & $\begin{array}{l}\text { Hardness } \\
\left(\mathrm{HV}_{\mathbf{0 . 0 2 5}}\right)\end{array}$ & $\begin{array}{c}\text { Thickness } \\
(\mu \mathrm{m})\end{array}$ & $\begin{array}{c}\text { Hardness } \\
\left(\mathrm{HV}_{\mathbf{0 . 1}}\right)\end{array}$ & \\
\hline S1 & $800^{\circ} \mathrm{C}, 2 \mathrm{~h}$ & 7.58 & 556 & 6.61 & 1175 & 8.75 \\
\hline $\mathbf{S 2}$ & $800^{\circ} \mathrm{C}, 4 \mathrm{~h}$ & 13.77 & 648 & 11.82 & 1204 & 20.18 \\
\hline S3 & $800^{\circ} \mathrm{C}, 6 \mathrm{~h}$ & 12.52 & 632 & 22.12 & 1359 & 28.15 \\
\hline S4 & $900^{\circ} \mathrm{C}, 2 \mathrm{~h}$ & 10.19 & 652 & 10.51 & 1216 & 13.92 \\
\hline S5 & $900^{\circ} \mathrm{C}, 4 \mathrm{~h}$ & 30.99 & 930 & 32.79 & 1666 & 44.65 \\
\hline S6 & $900^{\circ} \mathrm{C}, 6 \mathrm{~h}$ & 31.03 & 740 & 65.65 & 1787 & 42.78 \\
\hline S7 & $1000^{\circ} \mathrm{C}, 2 \mathrm{~h}$ & 12.21 & 630 & 12.45 & 1588 & 20.45 \\
\hline S8 & $1000^{\circ} \mathrm{C}, 4 \mathrm{~h}$ & 34.24 & 935 & 72.01 & 2154 & 43.12 \\
\hline S9 & $1000^{\circ} \mathrm{C}, 6 \mathrm{~h}$ & 33.85 & 812 & “92.03 & 2432 & 41.60 \\
\hline
\end{tabular}

As shown in Table 2, the increase in boriding temperature and duration time did not only contribute to the increase in the micro-hardness values of the boride layer but also to the growth in the thickness. The thicknesses of silicide and boride layer ranged from 7.58 to $34.24 \mu \mathrm{m}$ and 6.61 to $92.03 \mu \mathrm{m}$, respectively. While the hardness silicide layer ranged from 556-935 $\mathrm{HV}_{0.025}$ and boride layers ranged from 1175-2432 $\mathrm{HV}_{0.1}$ depending on boriding temperature and duration time. When compared to the literature, significantly higher hardness values and thicker boride layers were obtained [5-9]. This is attributed to formation of hard boride phases such as $\mathrm{CrB}$ and $\mathrm{Ni}_{2} \mathrm{~B}$ [13] that are discussed in detail by XRD analyses. Also, on hardness and layer thickness of formed boride layer boriding time it seems to be a more effective parameter rather than temperature..

Considering Table 2, it can be seen silicide layer increased with increasing boriding temperature. However, silicide layer increased while boriding time increased from $2 \mathrm{~h}$ to $4 \mathrm{~h}$ whereas silicide layer decreased when boriding time increased from $4 \mathrm{~h}$ to $6 \mathrm{~h}$. This situation shows that the $\mathrm{O}_{2}$ depleted after a certain period due to studied in Ar environment and in this way prevented the higher silicide layer formation. The hardness of the silicide layers ranged from 556 to $935 \mathrm{HV}_{0.025}$ and consistent with the literature data [6, $8]$.

Many studies indicate that the silicide layer is undesirable for wear resistance in borided Ni-based superalloys and should be removed in mechanical applications [5, 6, 9]. One reason is that the silicide and boride layers have different thermal expansion coefficients and this causes to cracks form in the silicide phase and/or the boundary between the boride and silicide phases during cooling. This often results in spalling and scaling under mechanical load. In addition, the hardness of silicide layer is lower than boride layer. Hence, the formation of a silicide layer, which to reaction with $\mathrm{SiC}$ contained in the boriding agents, is undesirable, particularly in wear applications. Although silicide layer formation not prevented with lower rate of silicide formation obtained according to previous study thanks to Ar atmosphere and using Ekrit powders. 


\subsection{XRD analysis of multi-phase coating layer}

XRD patterns of some of the borided samples are presented in Figure 3a-3d. A multi-phase coating layer formed depending on chemical composition of Inconel 625 superalloy and boriding agent. $\mathrm{Ni}_{2} \mathrm{~B}$ phase was formed in all process conditions according to $\mathrm{Ni}-\mathrm{B}$ equilibrium system. Silicide phases, which formed due to containing of $\mathrm{SiC}$ in Ekabor II powder, forms as $\mathrm{Ni}_{3} \mathrm{Si}$ at $800{ }^{\circ} \mathrm{C}$ and $\mathrm{Ni}_{2} \mathrm{Si}$ at 900 and $1000{ }^{\circ} \mathrm{C} . \mathrm{Cr}_{2} \mathrm{~B}, \mathrm{Cr}_{3} \mathrm{~B}_{4}$ and $\mathrm{Cr}_{5} \mathrm{~B}_{3}$ phases identified in $800^{\circ} \mathrm{C}$ for 2 and $6 \mathrm{~h}, 900{ }^{\circ} \mathrm{C}$ for $6 \mathrm{~h}$ and $1000^{\circ} \mathrm{C}$ for $6 \mathrm{~h}$, respectively. $\mathrm{Cr}_{5} \mathrm{~B}_{3}$ phase have effect on coating hardness by hindering the dislocation motion [14]. The highest hardness values obtained in this sample which formed $\mathrm{Cr}_{5} \mathrm{~B}_{3}$ phase. In addition minor phases $\mathrm{Fe}_{3} \mathrm{~B}, \mathrm{Fe}_{2} \mathrm{~B}, \mathrm{MoB}, \mathrm{MoB}_{2}, \mathrm{NbB}$, $\mathrm{NbB}_{2}$ and $\mathrm{Co}_{3} \mathrm{~B}$ were identified depending on chemical composition of Inconel 625 superalloy. This indicated that formation of phases such as $\mathrm{CrB}$ and $\mathrm{Ni}_{2} \mathrm{~B}$ provides higher hardness in the boride layer [13]. So higher hardness values obtained according to previous study. Dinc et. al., obtained $\mathrm{Ni}_{4} \mathrm{~B}_{3}, \mathrm{Ni}_{2} \mathrm{Si}$ and $\mathrm{FeB}$ whilw Deng et. al. FeNi, $\mathrm{Ni}_{2} \mathrm{~B}, \mathrm{Ni}_{2} \mathrm{Si}, \mathrm{Ni}_{4} \mathrm{~B}_{3}, \mathrm{Fe}_{2} \mathrm{~B}$ and $\mathrm{CrB}$ in Inconel 718 Ni-based superalloy [7, 10 ].
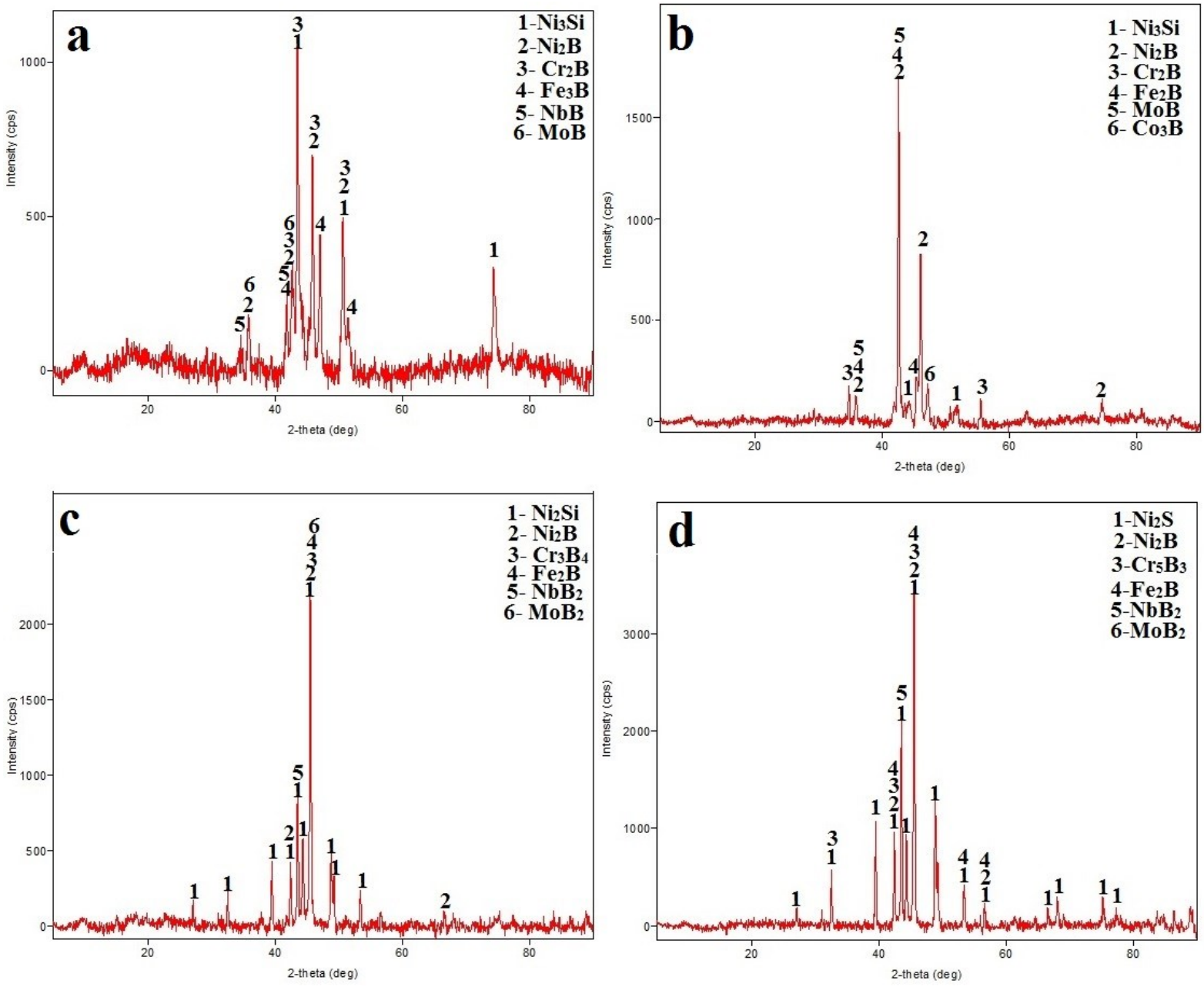

Figure 3: XRD pattern of borided Inconel 625 a) $800{ }^{\circ} \mathrm{C}$ for $2 \mathrm{~h} \mathrm{~b}$ ) $800{ }^{\circ} \mathrm{C}$ for $6 \mathrm{~h} \mathrm{c}$ ) $900{ }^{\circ} \mathrm{C}$ for $6 \mathrm{~h}$ and d) $1000{ }^{\circ} \mathrm{C}$ for $6 h$.

\subsection{Micro-abrasion wear tests}

To further evaluate the properties of the coatings, micro-abrasion wear tests were carried out at 5, 7.5 and 10 $\mathrm{N}$ load on both untreated and borided samples. The radius of wear track and volume loss of the worn samples depending on applied load are listed in Table 3 and a comparison chart for volumetric wear loss is given in Figure 4. 
Table 3: Radius of wear tack and calculated volume loss values for samples subjected to micro-abrasion wear testing.

\begin{tabular}{c|c|c|c|c|c|c}
\hline \multirow{2}{*}{ Samples } & \multicolumn{2}{|c|}{ Radius of wear track $(\boldsymbol{\mu m})$} & \multicolumn{3}{c}{ Volume loss $\left(\mathbf{1 0}^{-4} \mathbf{m m}^{3}\right)$} \\
\cline { 2 - 7 } & $\mathbf{5 N}$ & $\mathbf{7 . 5 N}$ & $\mathbf{1 0 N}$ & $\mathbf{5 N}$ & $\mathbf{7 . 5 N}$ & $\mathbf{1 0 N}$ \\
\hline S0 & 12222 & 1323 & 1438 & 86.14 & 118.35 & 165.19 \\
\hline S1 & 1089 & 1287 & 1348 & 54.33 & 105.99 & 127.55 \\
\hline S2 & 1073 & 1179 & 1307 & 51.21 & 74.65 & 112.73 \\
\hline S3 & 979 & 1096 & 1234 & 35.48 & 55.74 & 89.58 \\
\hline S4 & 1034 & 1102 & 1252 & 44.16 & 56.97 & 94.92 \\
\hline S5 & 956 & 1008 & 1066 & 32.26 & 39.88 & 49.88 \\
\hline S6 & 827 & 932 & 973 & 18.07 & 29.14 & 34.62 \\
\hline S7 & 978 & 1055 & 1189 & 35.34 & 47.85 & 77.20 \\
\hline S8 & 732 & 901 & 947 & 11.09 & 25.45 & 31.07 \\
\hline S9 & 726 & 845 & 945 & 10.73 & 19.69 & 30.80 \\
\hline
\end{tabular}

It can be seen from Table 3 that the wear track radius for the untreated samples are higher than all borided samples regardless of the boriding parameters. The radius of the wear track increased with increasing load. Correspondingly, the volume loss of the samples also increased with increasing load (Table 3 and Figure 4).

This increase can be attributed to the increased tension on the same particles as a result of increasing the load on the particles in abrasive solution. As the applied load on the particles, pinched between the sample surface and ball, increases it will give rise to a larger penetration depth for the abrasive particles into the surface. The hardness of the sample is one of the important parameters involved in this plunging process. Generally, increasing surface hardness provides more resistance to penetration. Consequently, wear due to two-body or three-body abrasion is reduced. Microstructure and macro-mechanical properties of the sample will be of importance here [15]. The particles which hold to each other in sizes of 30-40 $\mu \mathrm{m}$ due to the plastic deformation are removed off by abrasive cutting effect starting from their splat connection points, which are their weakest connections [16]. With that metal transfer takes place from the surface.

Considering the results of the wear tests, the borided samples tested under 5, 7.5 and $10 \mathrm{~N}$ loads showed about 8, 6 and 5 times less volume loss in comparison to their untreated counterparts, respectively. Reduction of the wear resistance ratio of borided samples with increasing force can be explained as follows. With increasing the load on the abrasive particles (SiC) give rise to fragmentation of SiC particles. So that the $\mathrm{SiC}$ particles have more sharp edges and act as the secondary abrasive particles. Eventually this give rise to increases in volume loss.

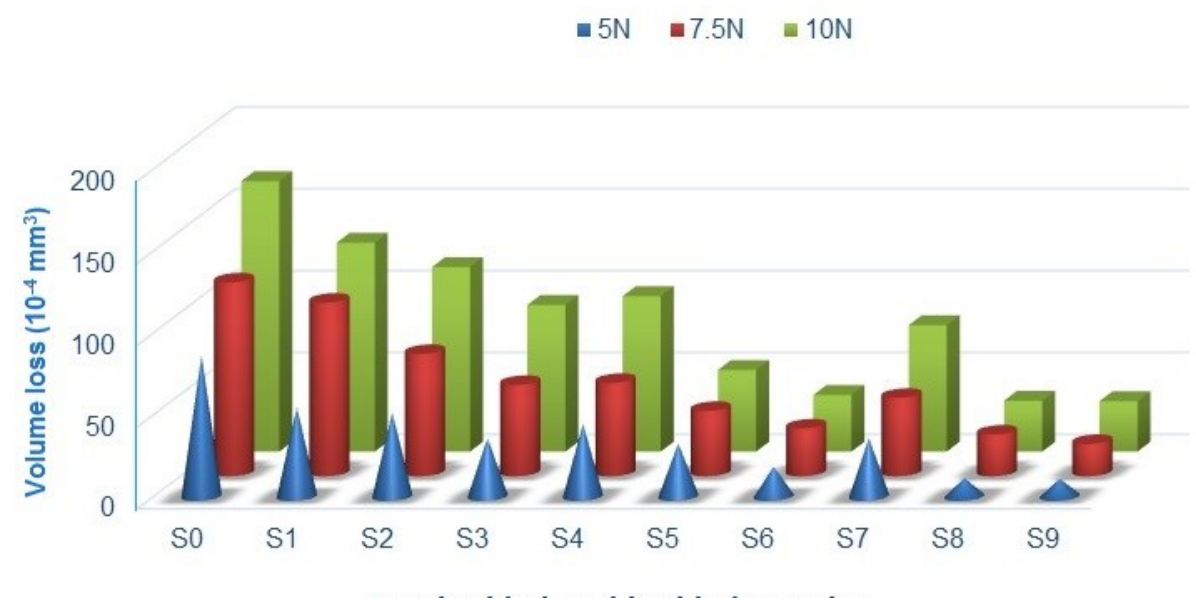

Figure 4: Volume loss of the samples subjected to fixed ball micro-abrasion wear test depending on applied load. 
On the other hand, the hardness of the samples also have a great effect on the wear resistance of the samples [11, 15, 17-19]. As the best wear resistance was obtained in the highest hardness samples and wear resistance decreased in accordance with decrease in hardness (Figure 4). This supports the often observed thesis, put forward by many studies, that hardness is one of the important parameters that increase wear resistance of the materials. This can be attributed to some degree on the force that is transmitted onto the abrasive particles. The penetration depth of the abrasive particles decreases on harder surfaces and this is what leads to lower volume losses in these materials.

The relative movement of the abrasive particles between the ball and the worn sample identify the type of occurring wear mechanism in worn sample [20]. If the abrasive particles do not move on the surface of the ball a series parallel groves form on the worn surface. This called two body abrasion or grooving-type wear. On the other hand, if the abrasive particles are free to move between the ball and worn surface, threebody abrasion or rolling-type wear occurs $[16,20]$. An SEM view of the Inconel 625 sample, worn at $90 \mathrm{rpm}$ under a) $5 \mathrm{~N}$ b) $7.5 \mathrm{~N} \mathrm{c}$ ) $10 \mathrm{~N}$ in wt. $25 \% \mathrm{SiC}$ abrasive suspensions, is shown in Figure 5.
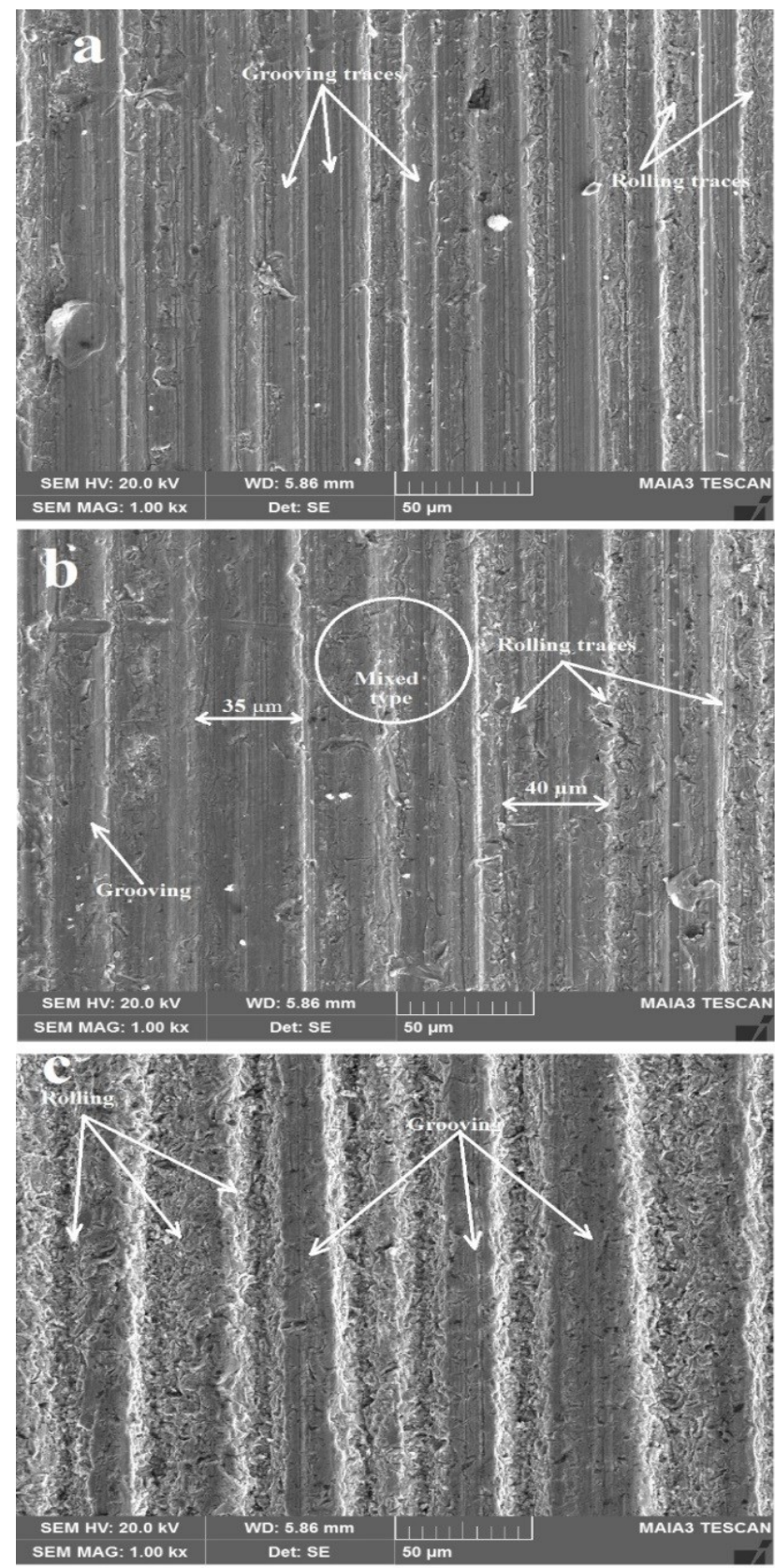

Figure 5: SEM image of wear track of the untreated Inconel 625 , subjected to the wear process in the a) $5 \mathrm{~N} \mathrm{~b}) 7.5 \mathrm{~N}$ c) $10 \mathrm{~N}$ in wt. $25 \% \mathrm{SiC}$ abrasive concentration solution. 
From Figure 5 it can be seen that the predominant wear mechanism of untreated Inconel 625 was grooving at $5 \mathrm{~N}$ and $7.5 \mathrm{~N}$ load. The main difference between wear surfaces observed at $5 \mathrm{~N}$ and $7.5 \mathrm{~N}$ parameters is the width of the wear groove, which appears wider at $7.5 \mathrm{~N}$ (Figure 5b). However, in the sample worn under $10 \mathrm{~N}$, there is evidence of grooving some regions of the surface and rolling on other regions. This is related with the increase of applied load. As applied load is the most effective parameter in the abrasion of particles on the surface of the sample due to the shear effect caused by the ball rolling down. Consequently, the increase in applied load was provide easier removing material from the surface and this was facilitated the movement of abrasive particle between the ball and worn surface. So in the form of rolling traces formed instead of groove trace. However, this is only valid in cases where the hardness of the abrasive particle higher than wearing surfaces.

Many of studies have been reported that the mechanical properties of the material has a significant effect on the type of wear $[11,15,17-19]$. SEM view of the sample with hardness 1204,1666 and $2432 \mathrm{HV}_{0.1}$ and worn under three different load presented in Figure 6, Figure 7 and Figure 8, respectively.

Figure $6 a-6 \mathrm{c}$ shows a SEM image of the worn surface of the sample borided at $800{ }^{\circ} \mathrm{C}$ for $4 \mathrm{~h}$. It can be seen from Figure $6 \mathrm{a}$ and $6 \mathrm{~b}$ the wear mechanism of the samples were grooving in the untreated Inconel 625 alloy. But with a higher load of $10 \mathrm{~N}$, in the same sample, mixed type (including roll and groove shape) wear tracks observed on boride layer (Figure 6c). This shows that increasing load can greatly influence the wear mechanism.
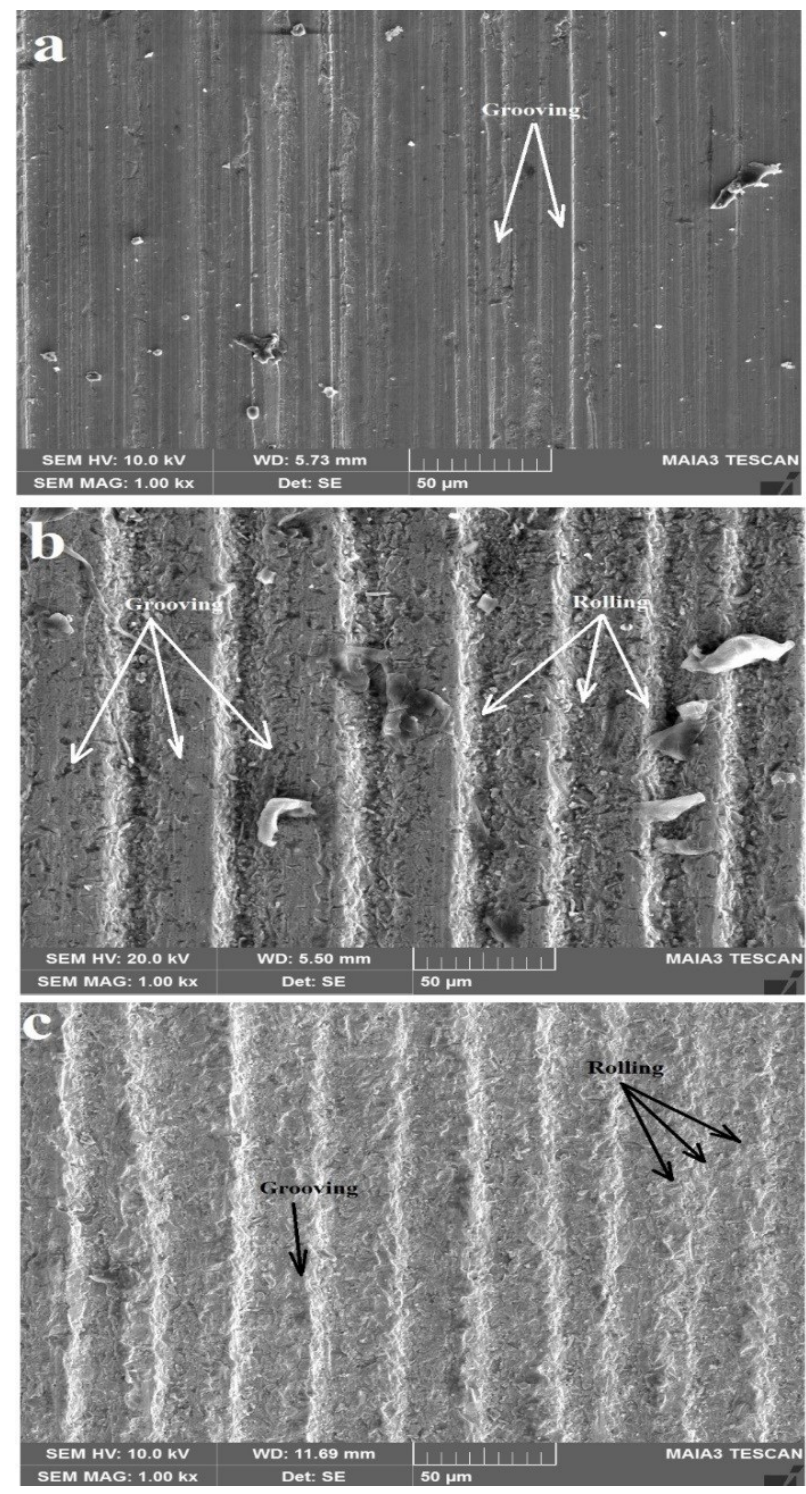

Figure 6: SEM view of the sample, borided for $4 \mathrm{~h}$ at $800^{\circ} \mathrm{C}$ then worn at $90 \mathrm{rpm}$ under a) $5 \mathrm{~N} \mathrm{~b}$ ) $7.5 \mathrm{~N} \mathrm{c}$ ) $10 \mathrm{~N}$ with $25 \% \mathrm{SiC}$ abrasive suspensions. 
Figure 7a-7c shows a SEM image of the worn surface of the sample borided at $900{ }^{\circ} \mathrm{C}$ for $4 \mathrm{~h}$.
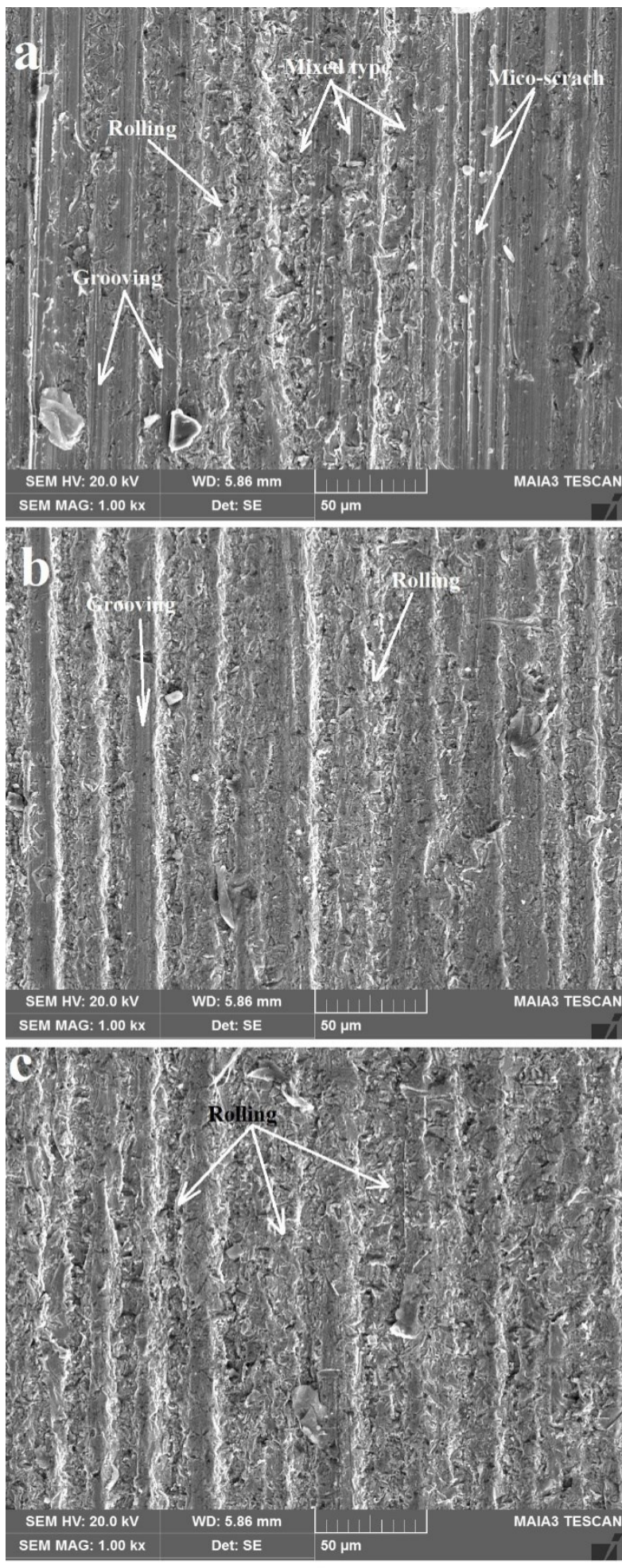

Figure 7: SEM view of the sample, borided for $4 \mathrm{~h}$ at $900^{\circ} \mathrm{C}$ then worn at $90 \mathrm{rpm}$ under a) $5 \mathrm{~N} \mathrm{~b}$ ) $7.5 \mathrm{~N} \mathrm{c)} 10 \mathrm{~N}$ with $25 \% \mathrm{SiC}$ abrasive suspensions.

It can be seen from Figure $7 \mathrm{a}$ and $7 \mathrm{~b}$ that the wear mechanism of the borided samples were of mixed type, showing evidence of both grooving- and rolling-type wear, but increasing the load changed the wear mechanism to rolling though traces of grooving observed in some regions (Figure $7 \mathrm{c}$ ). When considering Figure 8 small rolling wear tracks observed instead of deep grooving wear tracks. These traces of wear, as 
well as the volumetric losses indicate that the abrasive particles were not able to penetrate the hard boride layer. The highest wear resistance was obtained in the sample with highest hardness. In the other hand, when the low load $(5 \mathrm{~N})$ was applied, the predominant wear mechanism was also rolling even though it was still possible to see a few grooving wear track in some limited areas. When applied load increased to $7.5 \mathrm{~N}$ and 10 $\mathrm{N}$ the observed wear mechanism seemed to change completely to that of the rolling wear.
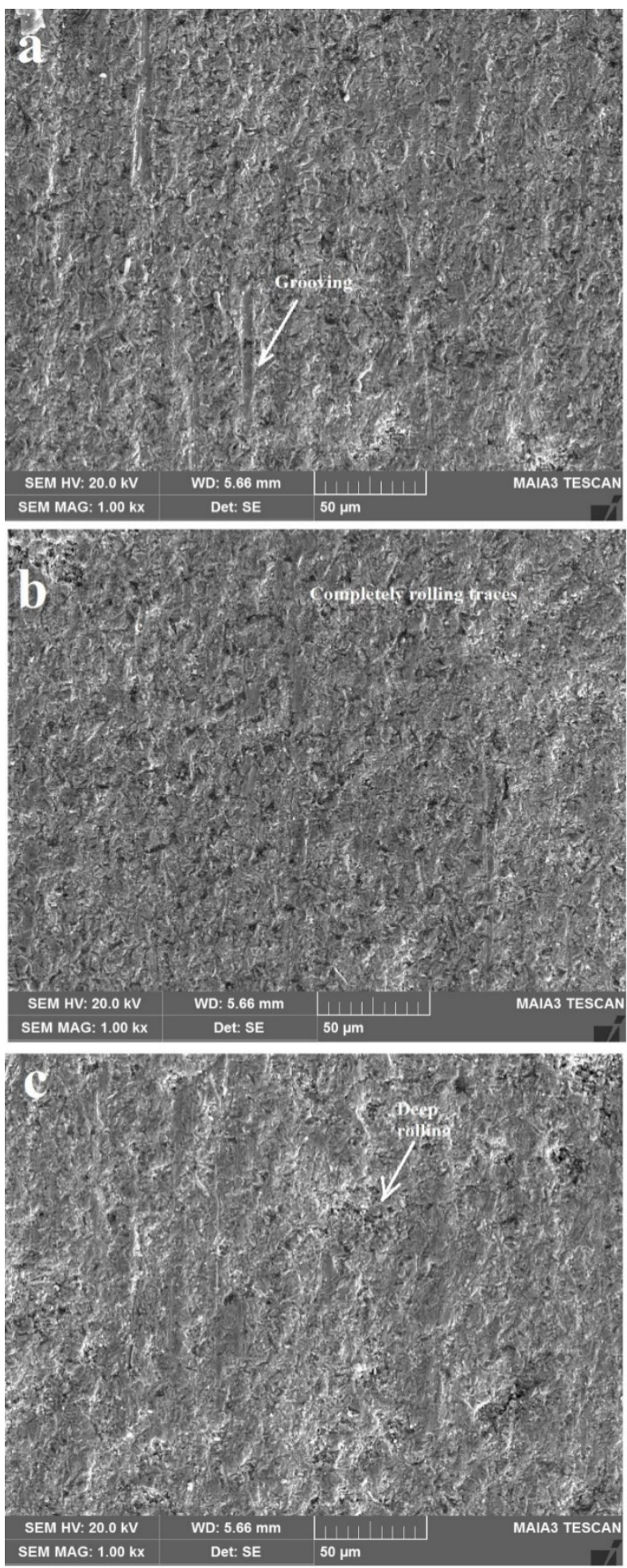

Figure 8: SEM view of the sample, borided for 6 hour at $1000^{\circ} \mathrm{C}$ then worn at $90 \mathrm{rpm}$ under a) $\left.\left.5 \mathrm{~N} \mathrm{~b}\right) 7.5 \mathrm{~N} \mathrm{c}\right) 10 \mathrm{~N}$ with wt.\% $25 \mathrm{SiC}$ abrasive suspensions. 
In conclusion, it can be said that both high surface hardness of borided samples and applied load were effective on changing the wear mechanism and wear resistance of Ni-based Inconel 625 superalloy. As the hardness and the applied load are important factors for plunging of abrasive particle into the surface. In addition high applied loads cause to breaking the abrasive particles, so the abrasive particles have more abrasive corner and this cause to growth in volume loss in comparison to low load.

\section{CONCLUSIONS}

In this study, the microstructure and mechanical properties of borided Inconel $625 \mathrm{Ni}$-based superalloys were investigated. From the obtained results, the following conclusions are drawn:

- Inconel $625 \mathrm{Ni}$-based superalloy was pack borided efficiently at temperatures of $800{ }^{\circ} \mathrm{C}, 900{ }^{\circ} \mathrm{C}$ and $1000^{\circ} \mathrm{C}$ for 2,4 and $6 \mathrm{~h}$ durations.

- The coating layers produced on the surface had a smooth morphology.

- The layer produced consisted of four zones: These zones, moving from the outer surface to the core were marked as the silicide layer, the multi-phase boride layer, the diffusion zone and the substrate respectively.

- The application of the boriding treatment under Ar atmosphere has a positive effect on reducing silicide formation especially at high duration time (6h).

- Increase in boriding temperature and duration time did not only contribute to increase in microhardness values of the boride layer but also to its thickness

- The micro-hardness of the multi-phase boride layer ranged between 1175 to $2432 \mathrm{HV}_{0.1}$. Higher values of micro-hardness is pointed to chromium borides, such as $\mathrm{Cr}_{4} \mathrm{~B}_{3}$ and $\mathrm{Cr}_{5} \mathrm{~B}_{3}$.

- All of the borided specimens displayed higher wear resistance in comparision with the untreated Inconel 625 superalloy.

- The wear resistance of the borided samples was about 8,6 and 5 times higher than the untreated samples under 5, 7.5 and $10 \mathrm{~N}$ load, respectively.

- The wear resistance of the borided specimens increased with increasing surface hardness.

- Increase in applied load resulted in increase wear losses for all samples.

- Both surface hardness and applied load were effective in changing the wear mechanism and wear resistance of the Ni-based Inconel 625 superalloy.

\section{ACKNOWLEDGMENTS}

This study was supported by the Mustafa Kemal University Research Council (Project Number 13911). The authors wish to thank Mustafa Kemal University Research Council for its grant contributions to this study.

\section{BIBLIOGRAPHY}

[1] GEDDES, B., LEON H AND HUANG X., Superalloys alloying and performance, ASM International Materials Park, Ohio, 2010.

[2] DONACIHE, M., DONACIHE, S., Superalloys A Technical Guide, 2 ed., ASM International, 2002.

[3] EISELSTEIN, H.L., TILLACK, D.J., In: Loria EA, editor, Superalloy 718, 625 and various derivatives, Warrendale, PA, TMS, 1991.

[4] SPECIAL METALS CORPORATION, INCONEL and INCOLOY are trademarks of the Special Metals Corporation group of companies, 2013.

[5] PETROVA, R.S., SUWATTANANONT, N., SAMARDZIC, V., "The effect of boronizing on metallic alloys for automotive applications", J. Mater. Eng. Perform., v. 17, n. 3, pp. 340-345, 2008.

[6] MUHAMMAD, W., HUSSAIN, K., TAUQIR, A., et al., "Evaluation of halide-activated pack boriding of inconel 722", Metallurgical and Materials Transactions A, v. 30, n. 3, pp. 670-675, 1999.

[7] DINC, H., MOTELLABZADEH, A., BAYDOGAN, M., et al., "Thermochemical boriding of Inconel 718 superalloy", Academic Journal of Science, v. 2, n. 2, 2013.

[8] KULKA, M., DZIARSKI, P., MAKUCH, N., et al., "Microstructure and properties of laser-borided In- 
conel 600-alloy", Applied Surface Science, v. 284, pp. 757-771, 2013.

[9] MAKUCH, N., KULKA, M., "Microstructural characterization and some mechanical properties of gasborided Inconel 600-alloy", Applied Surface Science, v. 314, pp. 1007-1018, 2014.

[10] DENG, D., WANG, C., LIU, Q., et al., "Effect of standard heat treatment on microstructure and properties of borided Inconel 718”, Trans. Nonferrous Met. Soc. China., v. 25, pp. 25437-25443, 2015.

[11] GUNEN, A., KANCA, E., DEMIR, M., et al., "Micro-abrasion wear behavior of fast borided steel tooth drill bits", Tribology Transactions, v.60, n.2, 2016.

[12] ULUTAN, M., YILDIRIM, M.M., CELIK, O.N., et al., " "Tribological properties of borided AISI 4140 steel with the powder pack-boriding method”, Tribology Letters, v. 38, pp. 231-36, 2010.

[13] SiNHA, A. K., Boriding (Boronising), ASM Handbook, v. 4, pp. 437-447, 1991.

[14] LIU, S.L., ZHENG, X.P., "Microstructure and properties of AC-HVAF sprayed Ni60/WC composite coating", J. Alloy. Compd., v. 480, pp. 254-258, 2009.

[15] HUANG, S., SUNN, D., WANG, W., et al., "Microstructures and properties of in-situ TiC particles reinforced Ni-based composite coatings prepared by plasma spray welding", Ceramics International, v. 41, pp. 12202-12210, 2015.

[16] KURT, B., KUÇUK, Y., GOK, M.S., "Microabrasion wear behavior of VC and $\mathrm{CrC}$ coatings deposited by thermoreactive diffusion technique", Tribology Transactions, v. 57, n. 2, 2014.

[17] KARAOGLANLI, A.C., CALISKAN, H., GOK, M. S., et al., "Acomparative study of the microabrasion wear behavior of CoNiCrAlY coatings fabricated by APS, HVOF, and CGDS techniques", Tribology Transactions, v.57, n. 1, pp. 11-14, 2014.

[18] GUNEN, A., KUÇUK, Y., ER, Y., et al., "Effect of the powder particle size on the wear behavior of boronized AISI 304 stainless steel'”, Material Testing, v. 57, n. 5, pp. 468-473, 2015.

[19] GUNES, I., YILDIZ, I., "Investigation of adhesion and tribological behavior of borided AISI 310 stainless steel"'Materia-Rio De Janeiro, v. 21, n. 1, pp. 61-71, 2016.

[20] BATISTA, J.C.A., MATTHEWS, A., GODOY, C., "Micro abrasive wear of PVD duplex and singlelayered coatings", Surface Coating Technology, v. 142-144, pp. 1137-1143, 2001. 